\title{
Simultaneous determination of methaqaulone, saccharin, paracetamol, and phenacetin in illicit drug samples by hplc
}

\author{
Mohd Idris" ${ }^{*}$, Cijo John', Priyankar Ghosh¹, Sudhir Kumar Shukla ${ }^{2}$ and Tulsidas Ramachandra Rao Baggi ${ }^{3}$
}

\begin{abstract}
Background: Saccharin, a low calorie artificial sweetener was found as a new diluent / adulterant present along with paracetamol and phenacetin in an illicit methaqualone sample.

Methods: All these components were simultaneously analyzed by the proposed reverse phase high performance liquid chromatography method using $C_{18}$ column using acetonitrile: water $(90: 10 \mathrm{v} / \mathrm{V})$ as mobile phase with a flow rate of $1 \mathrm{~mL} / \mathrm{min}$.

Results: The percentages of saccharin, phenacetin, paracetamol and methaqualone in illicit drug sample were found to be 15.0, 45.6, 25.1 and 12.0 respectively. The method was validated for limit of detection, limit of quantification, linearity, accuracy, precision and reproducibility with the help of the exhibit and simulated samples.

Conclusions: The proposed method is simple, accurate and fast. It can be applied to the routine analysis of illicit methaqualone samples as well as for their impurity profiles for tracing the origin.
\end{abstract}

Keywords: Saccharin, Methaqualone, Diluents, Illicit drug samples, HPLC, Drug profiling

\section{Background}

The ever-growing problem of drug abuse is of great concern to the society. The drugs of abuse may be encountered in forensic practice in either pure form, diluted and/ or adulterated forms. The reasons for the presence of many substances as impurities, diluents or adulterants in illicit drugs are often varied. Sometimes it may be unintentional because of the imperfect and bad manufacturing and laboratory practices. Most of the time these diluents and adulterants could be added as cutting agents to increase the bulk, dilute, complement or enhance the effects of the drugs and to mimic the taste of a genuine drug. The evidence suggests that illicit drugs are more commonly adulterated with either neutraceuticals such as sucrose, lactose, dextrose, mannitol and vitamins or pharmaceuticals that will mimic the taste of illicit drugs such as quinine, caffeine, paracetamol and aspirin or some innocuous substances such as talc, starch, chalk and magnesium stearate (Behrman 2008) etc. On one hand the identification as

\footnotetext{
*Correspondence: md_idris3@yahoo.com

${ }^{1}$ Chemistry Division, Central Forensic Science Laboratory, Hyderabad, India

Full list of author information is available at the end of the article
}

well as determination of a controlled substance is important for forensic science laboratories for prosecutorial purposes and on the other hand profiling of decomposition products, side reaction products, precursors, impurities, solvents, adulterants and diluents are of prime importance to trace the geographical origin of the illicit sample.

Paracetamol or acetaminophen, (Figure 1) is a widely used over-the-counter analgesic (pain reliever) and antipyretic (fever reducer). It is commonly used for the relief of headaches, other minor aches and pains, and is a major ingredient in numerous cold and flu remedies. In combination with opioid analgesics, paracetamol can also be used in the management of more severe pain such as post surgical pain and providing palliative care in advanced cancer patients. It was found as adulterant in illicit heroin, methaqualone, phenobarbitone, cocaine, methamphetamine (Atasoy et al. 1988; Battisti et al. 2006; Brunt et al. 2009).

Phenacetin (Figure 2) is an analgesic, once widely used but nowadays its use has been declined because of its adverse effects. It was reported as adulterant in illicit cocaine, methaqualone and heroin samples (Fucci 2004; Fucci \& Giovanni 1998; Furst 2000). 


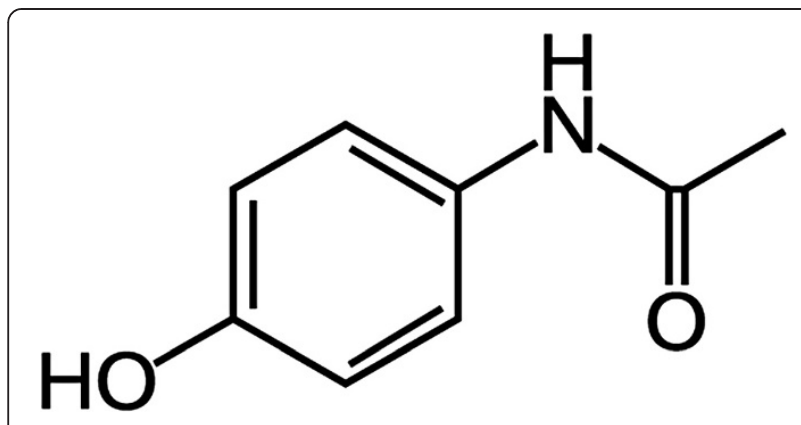

Figure 1 Paracetamol.

Methaqualone (Figure 3) is a sedative-hypnotic drug that is similar in effect to barbiturates, a general central nervous system depressant. It was widely used in the 1960s and 1970s as a hypnotic, for the treatment of insomnia, and as a sedative and muscle relaxant. It has also been used illegally as a recreational drug, commonly known as Mandrax. The drug was used during sexual activity because of heightened sensitivity and lowered inhibition coupled with relaxation and euphoria (Kacker \& Zaheer 1951; Smyth et al. 1973).

Saccharin (1, 2-benzisothiazol-3(2H)-one-1, 1-dioxide), (Figure 4) is a non-glucose, low-calorie sugar substitute. It is found to be new cutting agent added in bulk or as diluent in illicit drugs because of its easy availability and low cost. Earlier in a study it was reported as diluent in illicit cocaine samples (Fucci \& De Giovanni 1998). But in some recent cases saccharin was found in illicit methaqualone samples along with paracetamol and phenacetin.

Saccharin was determined individually in soft drinks, dietetic food samples (Filho \& Nobrega 1994; Fo et al. 1993), determined simultaneously along with preservatives and flavoring agents in drinks (Ikai et al. 1988; Terada \& Sakade 1985), also along with other nonnutritive sweeteners in dietetic samples (Chen et al. 1997; Biemer 1989; Zhu et al. 2005; Sastry et al. 1995; Valley et al. 2007). It was also determined individually in faces sample (Tibbels \& Smith 1988). Limited references are available on the occurrence and determination of saccharin as diluent/adulterant in illicit drug samples<smiles>CCOc1ccc(NC(C)=O)cc1</smiles>

Figure 2 Phenacetin.

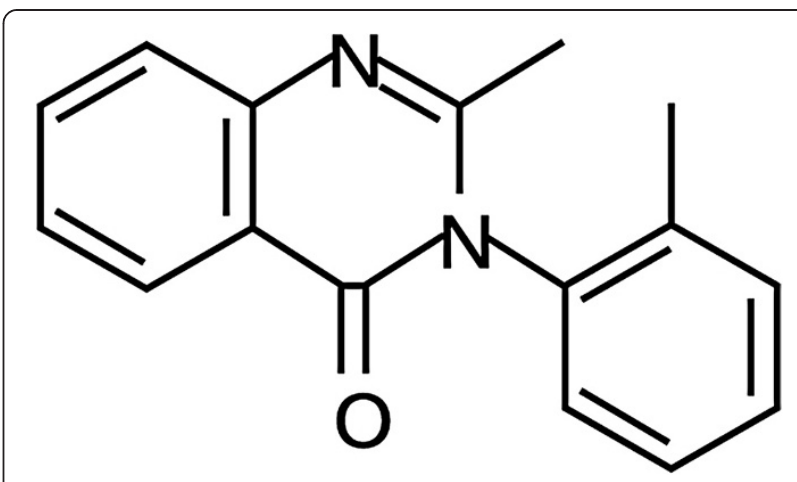

Figure 3 Methaqualone.

(Fucci \& De Giovanni 1998). Most of the methods of analysis of drugs and other compounds were designed for their determination in routine pharmaceutical analysis and not for illicit drugs which might contain a variety of drugs and chemicals as diluents and adulterants, which are not present in official preparations. When the standard pharmaceutical procedures are applied to the illicit drugs they are fraught with interferences, difficulties in separation, identification and quantification. Therefore, there is always a need to develop new methods and procedures for the analysis of illicit drug samples where we can separate the adulterants, diluents and other impurities encountered in the forensic samples.

In this presentation a simple liquid chromatographic method has been described for the simultaneous determination of saccharin, paracetamol, phenacetin and

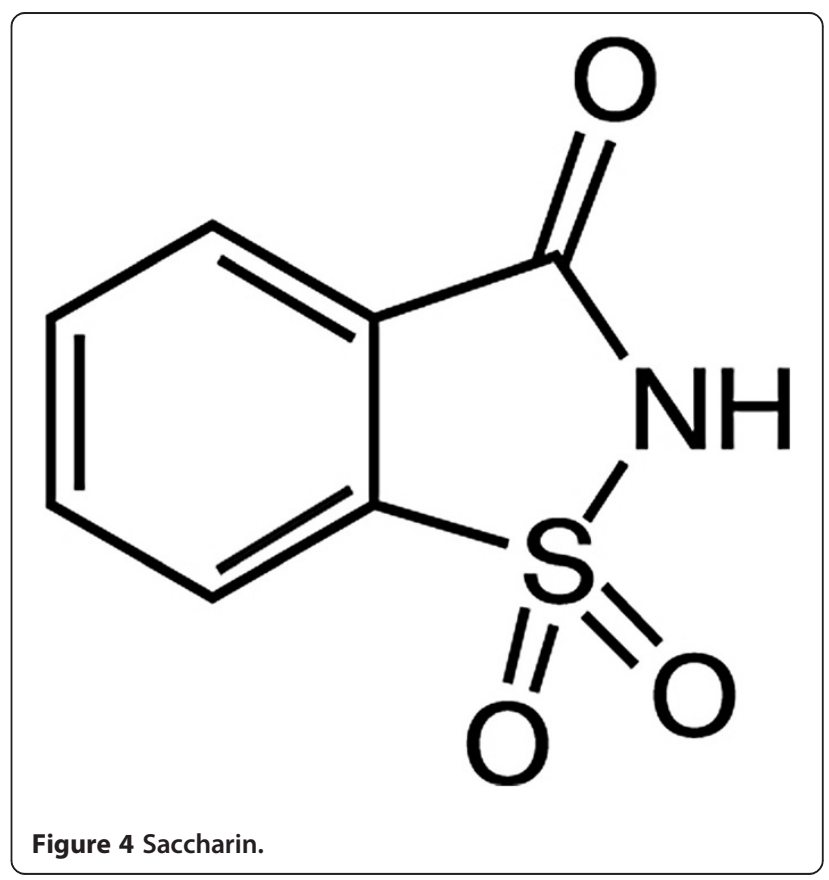


methaqualone in an illicit methaqualone samples. To demonstrate the usefulness of this method samples were also analyzed by employing Clarke's HPLC methods (Anthony et al. 2003) for determination of paracetamol, phenacetin and methaqualone where as Tibbels and Smith method (Tibbels \& Smith 1988) was used for analysis of saccharin.

\section{Experimental}

\section{Chemicals and reagents}

Saccharin was supllied by Kare Labs (India), paracetamol; phenacetin and methaqualone were purchased from Sigma-Aldrich (India). HPLC grade acetonitrile and water were purchased from Qualigens (India).

\section{Apparatus}

High Performance Liquid Chromatography (HPLC) System (Waters) consisting of a 600E controller pump, a 717 plus auto sampler, 2996 PDA detector and an inlinedegasser. Millinium32 software for data processing and $\mathrm{C}_{18}$ (Waters, Spherisorb 5 um ODS2, $4.6 \times 250 \mathrm{~mm}$ ) analytical column was used for separation.

\section{Standard preparation}

A standard stock solution containing a mixture of saccharin, phenacetin, paracetamol, and methaqualone having a concentration of $2 \mathrm{mg} / \mathrm{mL}$ of each of these substances was prepared in the mobile phase. The stock solution was further diluted with mobile phase to give the five different concentrations (containing saccharin, paracetamol, phenacetin and methaqualone in the range of $0.2 \mu \mathrm{g} / 10 \mu \mathrm{L}$ to $1.8 \mu \mathrm{g} / 10 \mu \mathrm{L}, 0.4 \mu \mathrm{g} / 10 \mu \mathrm{L}$ to $2 \mu \mathrm{g} / 10 \mu \mathrm{L}, 0.4 \mu \mathrm{g} / 10 \mu \mathrm{L}$ to $2 \mu \mathrm{g} / 10 \mu \mathrm{L}$ and $0.2 \mu \mathrm{g} / 10 \mu \mathrm{L}$ to $1 \mu \mathrm{g} / 10 \mu \mathrm{L}$, respectively). Five replicates of each of these five solutions were injected for plotting the calibration curve.

For limit of detection and limit of quantification a standard solution containing each of saccharin, phenacetin, paracetamol and methaqualone $(1 \mathrm{mg} / \mathrm{mL}$ each) was diluted to give the different concentrations $(0.05 \mu \mathrm{g} /$ $10 \mu \mathrm{L}$ to $2 \mu \mathrm{g} / 10 \mu \mathrm{L})$. Recovery studies were carried out by standard addition method where three different concentrations of above said components were prepared with in the calibration range of corresponding components.

\section{Sample preparation}

A homogenized representative sample $(10 \mathrm{mg})$ was transferred to a $10 \mathrm{~mL}$ volumetric flask and made up to the mark with mobile phase with intermittent shaking. Simulated samples were simultaneously prepared by mixing methaqualone, phenacetin, paracetamol and saccharin in different proportions. The simulated samples were analyzed by the proposed method for validation studies.

Standards and samples were ultrasonicated for $15 \mathrm{~min}$ and filtered through a Whatmann No.1 (Cellulose,
Particle retention of $11 \mu \mathrm{m}$ ) filter paper prior to injection into the HPLC system.

\section{Chromatography}

Chromatography was carried out at ambient temperature. The mobile phase consisted of acetonitrile and water (90:10). The flow-rate of the mobile phase was $1 \mathrm{~mL} / \mathrm{min}$. $10 \mu \mathrm{L}$ of each of the standard solutions of the four compounds were injected in the HPLC to prepare a calibration graph. Then ten micro liters of sample solution was injected and concentration of each component was determined through the calibration graphs of the respective standards.

\section{Method validation}

Preliminary validation of the method was performed by checking the linearity, precision, recovery, detection and quantification limits, and repeatability.

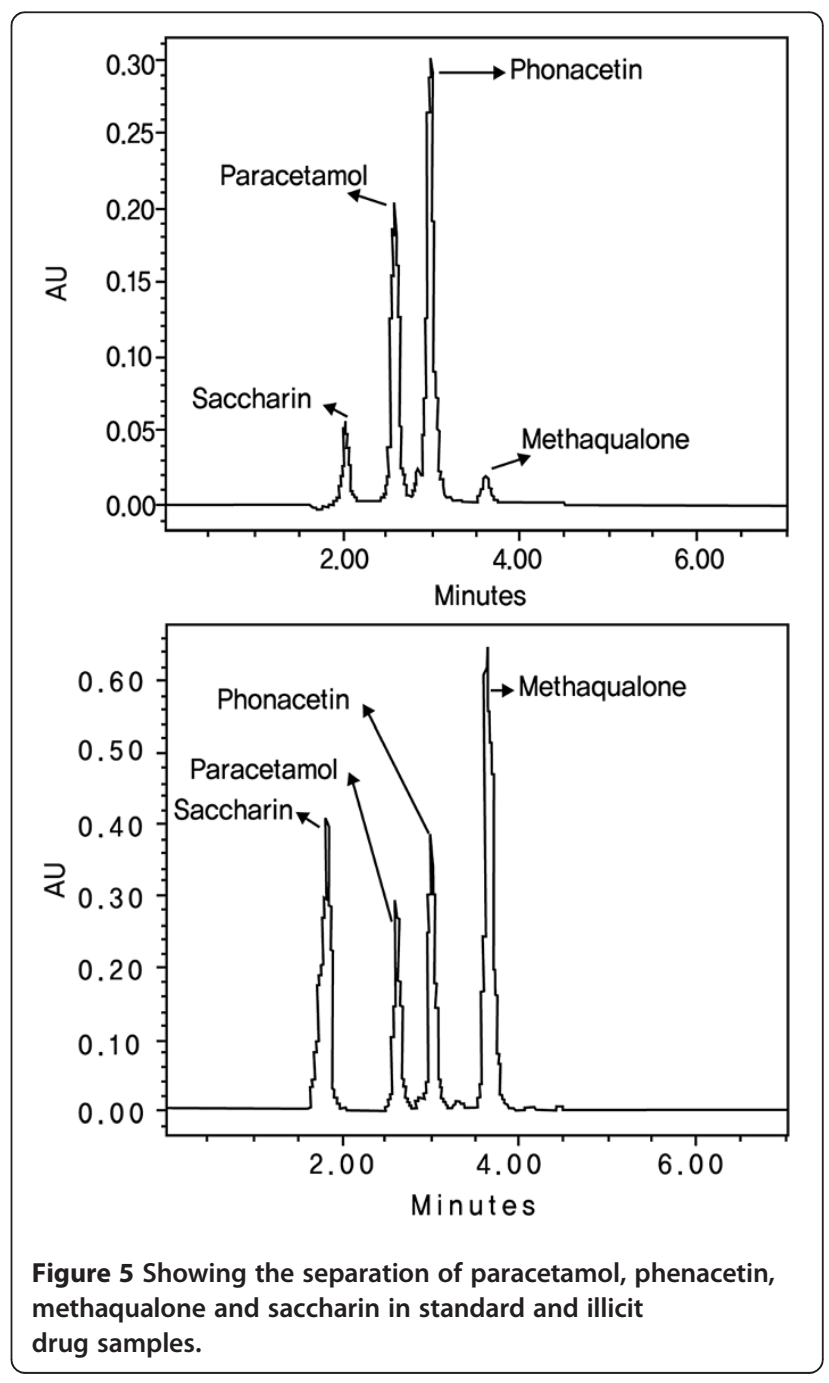




\section{Limits of detection and determination}

The detection and quantification limit were determined based on signal $(\mathrm{S})$ to noise $(\mathrm{N})$ ratio by injecting diluted solutions (made from stock solution $(2 \mathrm{mg} / \mathrm{mL})$ ) into the HPLC system. Limit of detection (LOD) was calculated as $\mathrm{S} / \mathrm{N} \times 3$ where as limit of quantification (LOQ) was calculated as $\mathrm{S} / \mathrm{N} \times 10$.

\section{Linearity}

For linearity checking Stock solution $(2 \mathrm{mg} / \mathrm{mL})$ containing a mixture of saccharin, phenacetin, paracetamol and methaqualone was further diluted with mobile phase to give the final concentration of $0.1 \mu \mathrm{g} / \mathrm{mL}$. And these solutions were injected into the HPLC system and the resultants peak areas of each component were recorded.

\section{Precision}

The precision of the method was evaluated on the basis of analyzing the three different concentrations of each component in the linearity range for repeating three times.

\section{Recovery/accuracy}

The accuracy of the method was expressed as the percentage recovery of each component. Recovery studies were carried out by standard addition method where three different concentrations of above said components were prepared with in the calibration range of corresponding components. And also recovery study was carried out by using simulated samples.

\section{Repeatability}

The consistency of the results for the same analytes samples were checked by repeating the experiment for 6 times per day (intraday) and consecutive for 3 days (interday). And standard deviation of the repeated recovery values was calculated.

\section{Robustness}

Robustness is a measure of a method's immunity to small but deliberate variations in the conditions used. Acetonitrile, water ratio $( \pm 10 \%)$ and flow rate $( \pm 10 \%)$ were deliberately changed and effects were monitored.

Table 1 Showing the data of limit of detection, limit of quantification and linearity range

\begin{tabular}{cccc}
\hline Compound & $\begin{array}{c}\text { Limit of } \\
\text { detection } \\
\text { (LOD) }\end{array}$ & $\begin{array}{c}\text { Limit of } \\
\text { quantification } \\
\text { (LOQ) }\end{array}$ & $\begin{array}{c}\text { Linearity } \\
\text { range }\end{array}$ \\
\hline Saccharin & $15 \mathrm{ng}$ & $48 \mathrm{ng}$ & $200 \mathrm{ng}-1800 \mathrm{ng}$ \\
Phenacetin & $10 \mathrm{ng}$ & $33 \mathrm{ng}$ & $200 \mathrm{ng}-2000 \mathrm{ng}$ \\
Paracetamol & $6 \mathrm{ng}$ & $19 \mathrm{ng}$ & $100 \mathrm{ng}-2200 \mathrm{ng}$ \\
Methaqualone & $5 \mathrm{ng}$ & $16 \mathrm{ng}$ & $100 \mathrm{ng}-1400 \mathrm{ng}$ \\
\hline
\end{tabular}

Table 2 Showing the regression equation, slope and intercept value of calibration curve obtained for different analytes

\begin{tabular}{ccc}
\hline Analytes & $\begin{array}{c}\text { Regression equation } \\
\mathbf{y}=\mathbf{m} \mathbf{x}+\mathbf{c}\end{array}$ & Regression value $\left(\mathbf{R}^{\mathbf{2}}\right)$ \\
\hline Saccharin & $Y=1007.5 x+790110$ & $0 . .9991$ \\
Phenacetin & $Y=1348.5 x+139111$ & 0.9996 \\
Paracetamol & $Y=2420.6 x+37789$ & $0 . .9993$ \\
Methaqualone & $Y=5011.3 x-77962$ & 0.9982 \\
\hline
\end{tabular}

\section{Results and discussion}

In the analysis of illicit drugs like methaqualone, in addition to its identity and quantization, it is very important to give the complete profile of the sample with respect to the presence of active component, its decomposition products, side reaction products, impurities, adulterants and diluents so that this data can be compared and correlated with samples of known origin. Many methods are available for the analysis of individual components present in the samples. Analyzing individual components in different unknown samples is a time consuming and costly process. Under these circumstances methods which can determine the individual components simultaneously, accurately and quickly are desirable. The proposed method has been developed by keeping in view these factors. By the proposed method, which needs minimum sample preparation, it was possible to separate and determine saccharin, paracetamol, phenacetin and methaqualone simultaneously in illicit methaqualone samples.

The present HPLC method shows the well resolved peaks with a short analysis time of only 6 minutes. Saccharin, paracetamol, phenacetin and methaqualone were eluted at 2.0, 2.5, 3.0 and 3.6 minutes respectively

Table 3 Showing the recovery and precision data

\begin{tabular}{ccccc}
\hline Compound & $\begin{array}{c}\text { Expected } \\
\text { amount }\end{array}$ & $\begin{array}{c}\text { Amount } \\
\text { recovered in ng }\end{array}$ & $\begin{array}{c}\% \\
\text { Recovery }\end{array}$ & $\begin{array}{c}\mathbf{\pm S D} \\
{[\% \mathbf{~ n = 3} \text { ] }}\end{array}$ \\
\hline Saccharin & 600 & 600.16 & 100.02 & 4 \\
& 1000 & 1005.83 & 100.58 & 2.51 \\
Phenacetin & 1400 & 1408 & 100.57 & 3.51 \\
& 500 & 499.5 & 99.99 & 2.38 \\
& 1000 & 1015.33 & 101.53 & 2.73 \\
Paracetamol & 1500 & 1507.5 & 100.5 & 2.59 \\
& 500 & 507.16 & 101.43 & 2.27 \\
& 1000 & 1004.83 & 100.48 & 4.14 \\
& 1500 & 1500.66 & 100.04 & 4.66 \\
Methaqualone & 400 & 402.16 & 100.54 & 2.07 \\
& 600 & 598.33 & 99.72 & 3.28 \\
& 800 & 797.66 & 99.70 & 2.83 \\
\hline
\end{tabular}


Table 4 Showing intraday and interday reproducibility data

\begin{tabular}{ccccc}
\hline Compound & Intraday recovery value $(\mathbf{n}=\mathbf{6})$ & $\mathbf{\pm}$ S.D & Interday recovery value (3 days) & $\mathbf{\pm}$ S.D \\
\hline Saccharin & $100.02,101.31,100.98,99.99,104.53,101.54$ & 1.66 & $100.02,104.34,102.54$ & 2.16 \\
Phenacetin & $99.99,99.87,101.72,103.64,101.73,100.11$ & 1.47 & $98.99,101.76,102.70$ & 1.92 \\
Paracetamol & $101.43,102.70,101.11,100.68,101.99,99.76$ & 1.02 & $101.43,104.37,104.01$ & 1.60 \\
Methaqualone & $100.54,100.96,102.73,101.13,100.02,99.99$ & 1.05 & $100.54,98.67,103.54$ & 2.45 \\
\hline
\end{tabular}

(Figure 2) under the experimental conditions used. The samples were analyzed in the wavelength ranges from $210 \mathrm{~nm}$ to $350 \mathrm{~nm}$ by using PDA detector. For detection of saccharin, paracetamol, phenacetin and methaqualone an optimized wavelength of $238 \mathrm{~nm}$ was chosen. The mobile phase was optimized by varying mobile phase compositions and flow rate. It was found that mobile phase (acetonitrile: water, 90:10 v/v) with a flow rate of $1 \mathrm{~mL} / \mathrm{min}$ was found to be optimum for efficient resolution of the peaks (Figure 5).

The method was validated accordingly $\mathrm{ICH}$ guideline. The limit of detection (LOD), limit of quantification (LOQ), and linearity range and coefficient correlation data is presented in Table 1 . The recovery of this method was found to be better than 99\% (Table 2). And the standard deviation (+ SD) of this method was found to be in the range from 2 to 5 (Table 3). Intraday and interday studies also shows good reproducibility in respect of recovery (Table 4), and it was found to be precise and accurate. The method remained unaffected, by small but deliberate variations, in the LC flow rate $( \pm 10 \%)$ and mobile phase ratio $( \pm 10 \%)$. The quantification of the components was studied on simulated samples. The percentage of methaqualone, phenacetin, paracetamol and saccharin in a typical illicit drug sample as well as simulated samples in Table 5 .

\section{Conclusion}

The proposed method is simple, accurate, reproducible and fast. It can determine the methaqualone, the adulterants/ diluents including saccharin simultaneously. The present method can be routinely used for the analysis of these components in illicit methaqualone samples and it will be a valuable method for drug profiling.

Table 5 Percentage of amount found in different samples \& comparative correlation of new method with reference methods

\begin{tabular}{|c|c|c|c|c|c|}
\hline Sample & Compounds & $\begin{array}{l}\text { \% Amount } \\
\text { expected }\end{array}$ & $\begin{array}{l}\% \text { Amount found by } \\
\text { new method }\end{array}$ & $\begin{array}{l}\% \text { Amount found by } \\
\text { reference methods }\end{array}$ & $\pm S D(n=3)$ \\
\hline \multirow[t]{4}{*}{ Sample 1 (Unknown) } & \multirow{4}{*}{$\begin{array}{l}\text { Methaqualone Phenacetin } \\
\text { Paracetamol Saccharin }\end{array}$} & - & 12.04 & 12.45 & 0.28 \\
\hline & & - & 45.60 & 45.09 & 0.36 \\
\hline & & - & 25.08 & 26.18 & 0.77 \\
\hline & & - & 15.01 & 14.31 & 0.49 \\
\hline \multirow{4}{*}{$\begin{array}{l}\text { Sample } 2 \text { (Mixed different } \\
\text { proportion of four compounds) }\end{array}$} & \multirow{4}{*}{$\begin{array}{l}\text { Methaqualone Phenacetin } \\
\text { Paracetamol Saccharin }\end{array}$} & 25 & 26.15 & 24.68 & 1.03 \\
\hline & & 25 & 24.49 & 24.10 & 0.27 \\
\hline & & 25 & 23.98 & 25.35 & 0.96 \\
\hline & & 25 & 27.05 & 26.78 & 0.19 \\
\hline \multirow{4}{*}{$\begin{array}{l}\text { Sample } 3 \text { (Mixed different } \\
\text { proportion of four compounds) }\end{array}$} & \multirow{4}{*}{$\begin{array}{l}\text { Methaqualone Phenacetin } \\
\text { Paracetamol Saccharin }\end{array}$} & 20 & 18.92 & 21.35 & 1.71 \\
\hline & & 20 & 21.05 & 21.69 & 0.45 \\
\hline & & 30 & 28.19 & 30.70 & 1.77 \\
\hline & & 30 & 32.11 & 29.85 & 1.59 \\
\hline \multirow{4}{*}{$\begin{array}{l}\text { Sample } 4 \text { (Mixed different } \\
\text { proportion of four compounds) }\end{array}$} & \multirow{4}{*}{$\begin{array}{l}\text { Methaqualone Phenacetin } \\
\text { Paracetamol Saccharin }\end{array}$} & 30 & 31.98 & 30.51 & 1.03 \\
\hline & & 30 & 28.70 & 31.59 & 2.04 \\
\hline & & 20 & 19.25 & 18.75 & 0.35 \\
\hline & & 20 & 22.70 & 20.96 & 1.23 \\
\hline \multirow{4}{*}{$\begin{array}{l}\text { Sample } 5 \text { (Mixed different } \\
\text { proportion of four compounds) }\end{array}$} & \multirow{4}{*}{$\begin{array}{l}\text { Methaqualone Phenacetin } \\
\text { Paracetamol Saccharin }\end{array}$} & 35 & 33.69 & 36.68 & 2.11 \\
\hline & & 30 & 28.18 & 31.32 & 2.22 \\
\hline & & 20 & 21.83 & 18.96 & 2.02 \\
\hline & & 15 & 13.76 & 14.13 & 0.26 \\
\hline
\end{tabular}




\section{Competing interests}

The authors declare that they have no competing interests.

\section{Authors' contributions}

Ml design the experiment, carried out the experiment, and contributed in framing the article. CJ assisted in the analysis using HPLC. PG collected the samples, assisted in the framing of experiment. SKS and TRB contributed in designing the experiment and framing the article. All authors read and approved the final manuscript.

\section{Acknowledgement}

Two of the authors (MI and CJ) are grateful to Dr C. N. Bhattacharya, Chief Forensic Scientist I/C, Directorate of Forensic Science, Government of India, New Delhi, for providing them research fellowships. The authors would like to thank Mr. A.K.Ganjoo, Director, CFSL, Hyderabad for extending necessary facilities and giving constant encouragement during the course of this work. Our thanks are due to Mr. S.N. Rasool, JSO, CFSL, Hyderabad, India, for technical help. Authors also thanks to M/s Kare Labs (Goa, India) for providing Reference standard of Saccharin.

\section{Author details}

${ }^{1}$ Chemistry Division, Central Forensic Science Laboratory, Hyderabad, India.

${ }^{2}$ Chemistry Division, Central Forensic Science Laboratory, Chandigarh, India.

${ }^{3}$ Forensic Science Institute, Osmania University, Hyderabad, India.

Received: 13 March 2013 Accepted: 13 March 2013

Published: 18 April 2013

\section{References}

Anthony CM, Osselton MD, Widdop B (2003) Clarke's Analysis of Drugs and Poisons, vol 1 \& 2, 3rd edn. Pharmaceutical Pharmaceutical, London

Atasoy S, Bicer F, Acikkol M, Bilgic Z (1988) Illicit drug abuse in the Marmara region of Turkey. J Forensic Sci Int 38(1-2):75-81

Battisti MC, Noto AR, Nappo S, De A, Carlini E (2006) A profile of ecstasy (MDMA) use in Sao Paulo, Brazil: An ethnographic study. J Psycho Drugs 38(1):13-18

Behrman AD (2008) Luck of the Draw: Common Adulterants found in illicit Drugs. J Emer Nursing 34:80-82

Biemer TA (1989) Analysis of Saccharin, Acesulfame-K and Sodium Cyclamate by high performance ion chromatography. J Chromatogr A 463:463-468

Brunt TM, Rigter S, Hoek J, Vogels N, Van Dijk P, Niesink RJM (2009) An analysis of cocaine powder in the Netherlands: Content and health hazards due to adulterants. Addiction 104(5):798-805

Chen Q, Mou S, Liu K, Ni Z (1997) Simultaneous determination of four artificial sweeteners and citric acid by High-Performance Anion Exchange Chromatography. J Chromatogr A 771:135-143

Filho OF, Nobrega JA (1994) Flow injection potentiometric determination of Saccharin in dietary products with relocation of filtration unit. Talanta 41:731-734

Fo OF, Moraes AJ, Santos GD (1993) Potentiometric determination of Saccharin in dietary products using mercurous nitrate as titrant. Talanta 40:737-740

Fucci N (2004) Phenacetin and cocaine in a body packer. J Forensic Sci Int 141 (1):59-61

Fucci N, De Giovanni N (1998) Adulterants encountered in the illicit Cocaine market. J Forensic Sci Int 95:247-252

Fucci N, Giovanni ND (1998) Adulterants encountered in the illicit cocaine market. J Forensic Sci Int 95:247-252

Furst RT (2000) The re-engineering of heroin: An emerging heroin "cutting" trend in New York City. Addict Resear Theory 8(4):357-379

Ikai Y, Oka H, Kawamura N, Yamada M (1988) Simultaneous determination of nine food additives using High Performance Liquid Chromatography. J Chromatogr A 457:333-343

Kacker IK, Zaheer SH (1951) Potential Analgesics. Part I. Synthesis of substituted 4 Quinazolones.J Ind Chem Soc 28:344-346

Sastry CSP, Srinivas KR, Prasad KMMK, Krishnamacharyulu AG (1995) Rapid, routine method for the analysis of non-nutritive sweeteners in food stuffs. Analyst 120:1793-2012

Smyth RD, Lee JK, Polk A, Chemburkar PB, Savacool AM (1973) Bioavailability of methaqualone. J Clin Pharmacol 13(10):391-400

Terada H, Sakade Y (1985) Studies on the analysis of food additives by High Performance Liquid Chromatography: V. Simultaneous determination of preservatives and Saccharin in foods by ion-pair Chromatography. J Chromatogr A 346:333-340

Tibbels TS, Smith RA (1988) Determination of saccharin in diet and biological materials. J Chromatogr A 441:448-453

Valley LFC, Jimenez JFG, Valencia MC (2007) Simultaneous determination of antioxidants, preservatives and sweetener additives in food and cosmetics by flow injection analysis coupled to a monolithic column. J Anal Chim Acta 594:226-233

Zhu Y, Guo Y, Ye M (2005) Separation and simultaneous determination of four artificial sweeteners in food and beverages by ion chromatography. J Chromatogr A 1085:143-146

doi:10.1186/2093-3371-4-4

Cite this article as: Idris et al:: Simultaneous determination of methaqaulone, saccharin, paracetamol, and phenacetin in illicit drug samples by hplc. Journal of Analytical Science and Technology 2013 4:4.

\section{Submit your manuscript to a SpringerOpen ${ }^{\odot}$ journal and benefit from:}

- Convenient online submission

- Rigorous peer review

- Immediate publication on acceptance

- Open access: articles freely available online

- High visibility within the field

- Retaining the copyright to your article

Submit your next manuscript at springeropen.com 